\title{
GEOSPATIAL LEVELS OF RESEARCH AND OPERATION OF AGRIBUSINESS SUPPLY MANAGEMENT IN CANADA
}

\author{
'Igor SMYRNOV, Oksana KACHUR (SHMATOK) \\ Taras Shevchenko National University of Kyiv, Ukraine \\ 'smyrnov_ig@ukr.net
}

\begin{abstract}
Represented the features and achievements of Canadian agrologistics and supply management system - an important factor in the high efficiency of agriculture in Canada, which is known worldwide as one of the largest manufacturer and exporter of various agricultural products. Shown the mechanism of farm and tariff quotas functioning with the possibility of their exchange on the domestic market, which is now successfully proven in industrial poultry and dairy industry in Canada. Given recommendations for the use of Canadian supply management system in agriculture in Ukraine.
\end{abstract}

Key words: agrologistics, supply management, agribusiness, industrial poultry and dairy industries in Canada

UDC: 911

\section{ГЕОПРОСТОРОВІ РІВНІ ДОСЛІДЖЕННЯ ТА ФУНКЦІОНУВАННЯ СИСТЕМИ УПРАВЛІННЯ ПОСТАВКАМИ В АГРОПРОМИСЛОВОМУ КОМПЛЕКСІ КАНАДИ}

\author{
'Iгор СМИРНОВ, ОКСана КАЧУР (ШМАТОК) \\ Київський національний університет імені Тараса Шевченка, Україна \\ 'smyrnov_ig@ukr.net
}

\begin{abstract}
Анотація: Розкрито особливості та досягнення канадської системи агрологістики та управління поставками, яка $\epsilon$ важливим чинником високої ефективності агропромислового комплексу Канади, що відома у світі як один із найбільших виробників та експортерів різноманітної сільськогосподарської продукції. Висвітлено механізм функціонування фермерських та тарифних квот з можливістю їх обміну на внутрішньому ринку, який нині успішно себе зарекомендував у промисловому птахівництві та молочній індустрії Канади. Запропоновано рекомендації із застосування канадської системи управління поставками в агропромисловому комплексі Україні.
\end{abstract}

Ключові слова: агрологістика, управління поставками, агробізнес, промислове птахівництво, молочна промисловість Канади

Удк: 911

Постановка наукової проблеми. Логістичні підходи в сфері агропромислового бізнесу набувають останнім часом все більшої ваги в Україні, зокрема в нинішніх кризових умовах, коли агропромисловий комплекс висувається на перший план за своїм потенціаломтаекспортнимиможливостями, особливо у зовнішній торгівлі 3 країнами Свропейського союзу. Завдання реформування аграрного сектору України в умовах євроінтеграційного спрямування ㄲï економічного розвитку вимагає вивчення та впровадження передового досвіду в сфері агрологістики та управління поставками в агропромисловому бізнесі. Саме такий досвід має Канада, як один із найважливіших світових виробників та експортерів сільськогосподарської та харчової продукції. Це відноситься, насамперед, до канадської системи управління поставками в агропромисловому комплексі, важливим складником якої є підсистема фермерських та тарифних квот 3 можливістю їх обміну на внутрішньому ринку, яка нині успішно зарекомендувала себе у промисловому птахівництві та молочній промисловості Канади та його застосування в Україні.

(C) І. Смирнов, О. Качур
Літературні джерела та публікації 3 теми статті найбільш концентровано представлені у спеціальному випуску міжнародного науковопрактичного журналу «Логістика. Проблеми та рішення» № 4 за 2013 р. [1] та належать Косаревій Т. В. [3], Сумцю О. В. [8; 9], Смирнову І. Г. та Шматок О. В. [7], Чухрай Н. І. [10], Кучеровій Я. [4]. Особливу цікавість являють собою джерела, що розкривають особливості, досвід та досягнення агрологістики в різних країнах, зокрема в Голландії [6], Канаді [2], Польщі, Чехії [5, 319-327, 363-380] та інших країнах. Але цей напрямок потребує більш детального розгляду, зокрема, це стосується досвіду досягнень Канади.

Метою статті $є$ представити в Україні канадську систему агрологістики та управління поставками, яка успішно функціонує протягом останніх років у цій країні, що виділяється як великими обсягами аграрного виробництва та експорту у світі, так і високим рівнем ефективності агропромислового комплексу, важливим чинником якого є застосування логістичних підходів.

Виклад основного матеріалу. Канадська система агрологістики (управління поставками в агропромисловому комплексі) була запроваджена в 


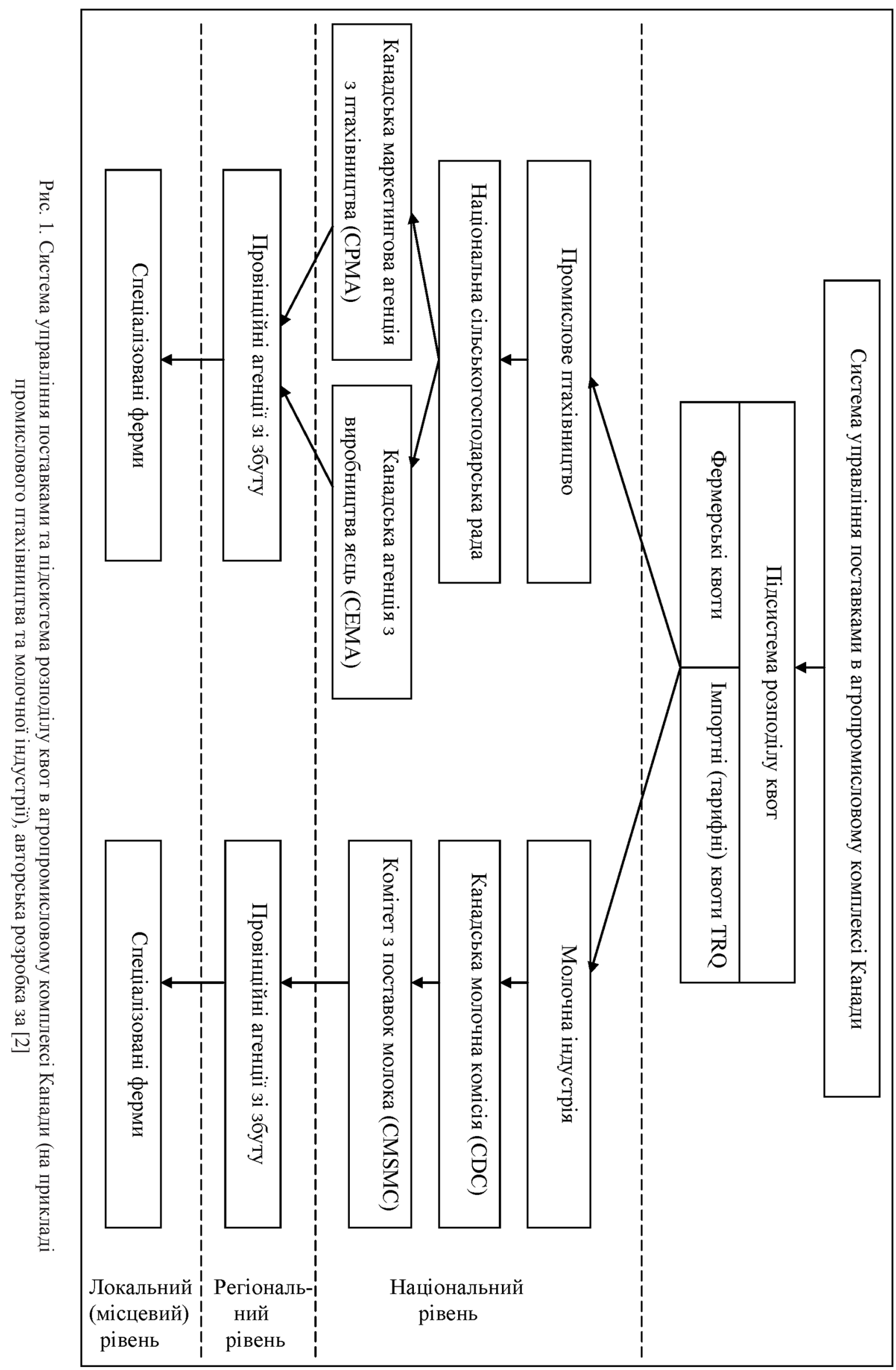


господарську систему Канади ще на початку 1970-х pp. та 3 постійно діючими змінами вона успішно функціонує й нині. Система управління поставками має низку позитивних особливостей, які можуть бути адаптовані до українських умов та використані для розробки ефективної економічної політики в галузях сільського господарства та харчової промисловості. До позитивних рис цієї системи можна віднести підвищення заможності споживачів та виробників за рахунок стабільності всередині агропромислового комплексу, збільшення прямих доходів виробників та працівників аграрного сектору, можливість розвитку системи обміну квотами на внутрішньому ринку, захист від іноземних виробників тощо. Також ця система адаптована до сучасних вимог СОT.

Канадська система агрологістики (управління поставками в агропромисловому комплексі) на сьогодні діє у двох підгалузях АПК Канади, а саме - у промисловому птахівництві (виробництві домашньої птиці) та молочному скотарстві та виробництві молочної продукції. Ці два напрямки є одними 3 ключових у агропромисловому комплексі Канади та займають 20 \% обсягу продажу аграрної продукції в цій країні. Істотно, що управління цими підгалузями здійснюється за допомогою агенцій зі збуту які створені в кожній провінції Канади. Повноваження агенцій поширюються на визначення рівня імпортних квот, управління поставками на місцевому рівні та встановлення місцевих цін на вироблену продукцію. Для реалізації цих повноважень агенції використовують два види квот. Перший - це фермерська квота, яка визначає, який обсяг продукції виробник може виробити, та вимірюється в певних одиницях продукції, що можуть бути продані кожного року. Такі квоти, виражені в кількісних показниках, є об'єктом торгу та обміну, тобто у такий спосіб фермер має можливість збільшити чи зменшити обсяги свого виробництва. Особливістю фермерських квот $є$ те, що вони зазвичай мають необмежений термін дії за умови виконання фермером певних умов. Крім цього, квоти $\epsilon$ власністю та управляються агенціями зі збуту провінцій. Торгівля квотами дозволена у більшості підгалузей АПК Канади, зокрема в молочній індустрії та промисловому птахівництві.

Другий вид - це імпортні квоти, які забезпечують обмеження імпорту кінцевої продукції АПК. Вони були запроваджені на початку 1970-х рр., нині згідно вимог СОТ вони називаються квотною тарифною ставкою або тарифною квотою (англ. Tariff Rate Quota, TRQ). Так як i фермерські квоти, тарифні квоти визначають певну кількість дозволеного імпорту, але відрізняються від перших тим, що надаються щорічно і немає гарантії їх отримання в наступному році тими власниками, що їх мали у минулому, хоча така ймовірність є доволі високою. Тарифні квоти визначає Міністерство закордонних справ та торгівлі Канади відповідно до торгівельних зобов'язань держави.

Участь уряду Канади в управлінні квотами доволі суттєва та різноманітна, але розрізняється залежно від виду продукції (рис. 1). Для фермерських квот спостерігається загальне правило, яке полягає у поділі юрисдикції між федеральним урядом та урядами провінції та спільне прийняття рішень у законодавчих та операційних процедурах. У випадку підгалузі промислового птахівництва присутність федерального уряду здійснюється через Національну сільськогосподарську раду (рис. 1), чий внесок полягає у допомозі групам виробників у створенні агенцій з продажу, включаючи управління міжпровінційними та експортними операціями, та їх взаємодію зі збутовими агенціями. Федеральний уряд сприяв розробці системи управління поставками в галузях АПК Канади, підготувавши законодавчу схему та дозволивши «впорядковані ринкові схеми». Прикладами національних агенцій у підгалузі промислового птахівництва Канади $є$ «Канадська маркетингова агенція 3 птахівництва» (СРМА) та «Канадська агенція з виробництва яєць» (CEMА).

Федеральний уряд Канади також відіграє важливу роль у діяльності молочної індустрії, зокрема, через Канадську молочну комісію (CDC), яка $є$ федеральним органом управління (рис. 1). Ця агенція більш глибоко задіяна у формуванні політики ефективного функціонування молочної підгалузі АПК, ніж у моделі управління промисловим птахівництвом. Так, Канадська молочна комісія рекомендує обсяги виробництва молока, визначає цінову політику щодо молочної продукції у межах всієї держави, контролює міжпровінційні угоди про спільні доходи від продажу, оперує складськими програмами та зазвичай координує виконання «Національного молочного ринкового плану». Більшість наведених функцій безпосередньо чи опосередковано впливає на рішення 3 фермерських квот. Федеральний уряд з провінціями бере участь в діяльності Комітетуз поставок молока(CMSMC), який приймає важливі для молочної підгалузі рішення, наприклад, який обсяг молока має бути вироблений, як воно має бути розподілено між провінціями тощо. У свою чергу уряди провінцій беруть участь в управлінні поставками та у вирішенні питань із квотами через провінційні агенції зі збуту. Останні задіяні у прийнятті рішень про політику розвитку підгалузі разом із федеральними структурами у Комітеті 3 поставок молока (CMSMC), наприклад, це питання, пов'язані 3 визначенням рівня загальних молочних квот, але більше вони займаються виконанням і контролем політики, розробленої на федеральному рівні. При цьому провінційні агенції із збуту зазвичай функціонують відносно незалежно від органів урядів провінцій, які можуть впливати на рішення агенцій шляхом переобрання та призначення їхніх членів.

Роль різних рівнів управління може бути представлена на прикладі алгоритму вирішення питання про розробку квот на локальному рівні молочної ферми. Цей процес починається 3 встановлення цін на молоко на рівні ферми та переробника, які визначаються рішенням федерального органу управління, обов'язковим для обох. Потім, знаючи ціни на молоко, оцінюється 
обсяг його споживання, тобто визначається загальна потреба в молоці (це робить Канадська молочна комісія). На цій підставі федерально-провінційний комітет CMSMC приймає кінцеве рішення про загальні необхідні поставки та визначає частку кожної провінції у квотах. Збільшення або зменшення загальних квот пропорційно відображається на формуванні провінційних. Останній крок у встановленні обсягу квот для індивідуальних фермерів відноситься до діяльності провінційних агенцій зі збуту та визначається індивідуально за фермами.

У промисловому птахівництві існує подібна схема розподілу квот, але вплив федерального управління на національні агенції з птахівництва $\epsilon$ меншим. Національні агенції оцінюють попит на продукт, рівень квот та співвідношення між провінційним імпортом та експортом. Ціни для ферм (або, принаймні, інтервал цін) встановлюються на національному рівні. У деяких випадках провінційні агенції зі збуту можуть коригувати ціни для своїх провінцій. У той же час національні агенції мають право на проведення обміну квот та іноді зобов'язують ферми отримати ліцензію. Провінційні птахівничі агенції зі збуту виконують ті самі завдання, що i агенції у молочній індустрії: зазвичай, вони розподіляють провінційні квоти серед виробників та контролюють їх виконання. Провінційні агенції зі збуту можуть вносити додаткові умови до розміщення квот, а саме: обов'язкове ліцензування, встановлення мінімального та максимального рівнів володіння квотами та продажу; визначають час володіння квотами; встановлюють податки та штрафи в різних ситуаціях; регулюють експортні процедури; розробляють спеціальні програми для нових фермерів.

Квотна тарифна ставка (TRQ) встановлюється Міністерством закордонних справ та міжнародної торгівлі Канади (MFAIT) згідно угоди COT, прийнятої в Уганді в 1995 р. При Міністерстві діє спеціальна агенція, яка адмініструє квоти це Експортно-імпортне контрольне бюро. Воно співпрацює $з$ національними агенціями, що також задіяні в адміністративних операціях. Провінційні та місцеві органи влади не беруть участь в розподілі цих квот, оскільки всі питання зовнішньої торгівлі відносяться до компетенції федеральних органів управління Канади. Роль MFAIT полягає у розміщенні тарифних квот (TRQ) серед приватних компаній та встановленні умов адміністрування цих квот. При цьому розміщення тарифних квот залежить від підгалузі АПК, зокрема, якщо існує підвищений попит або спостерігається його скорочення. Компанії, що мають тривалі зв'язки 3 розподілу продукції 3 певними дистриб'юторами, дістають пріоритет у розподілі тарифних квот. Іноді розміщення цих квот відбувається пропорційно наявності специфічного устаткування для виробничого процесу. В усіх інших випадках тарифні квоти розподіляються згідно засади «перший прийшов - перший отримав». Існує декілька обмежень щодо обсягу володіння TRQ для однієї компанії. Також немає ніяких грошових відносин у адмініструванні розміщення тарифних квот між отримувачем та управляючою агенцією, тобто неможливі аукціони з продажу тарифних квот (TRQ). Розміщення фермерських квот між індивідуальними фермами на початковому етапі відбулося ще у 1970-х рр. Квоти були розподілені безоплатно серед ферм, що вже виробляли продукцію, з урахуванням індивідуальних історій продажу. При цьому квоти зазвичай розподілялися пропорційно обсягу виробництва кожної ферми, використовуючи правило дистрибуції, наприклад, якщо ферма виробляла X\% провінційного обсягу, то вона отримувала Х\% квот післязапровадження системи управління поставками. У випадку зменшення обсягів виробництва після введення системи управління поставками квоти розподілялися пропорційно у меншому обсязі для усіх учасників.

Щодо імпортних квот, то, як вже зазначалося, вони мають термін життя один рік, тобто кожного року здійснюється нове їх розміщення, яке, так як i для фермерських квот, $є$ безкоштовним та заснованим на засаді тривалості відносин. Але федеральний уряд Канади однозначно дає до зрозуміння, що щорічне розміщення квот є змінним та тримачі квот не можуть ïх поновлювати щорічно автоматично. У деяких секторах АПК групи фірм можуть розраховувати на певні преференції у розміщенні квот, якщо ці фірми виконують важливе завдання національної ваги або мають якусь іншу подібну причину. Приміром, фірма чи група фірм матимуть пріоритет у розподілі квот, якщо їм потрібна сировина для виробничого процесу, яку вони набувають у системі управління поставками за нижчою ціною, оскільки їм необхідно конкурувати на ринках США. До інших можливих опцій розподілу квот у канадський системі управління поставками в АПК можна віднести аукціони, але вони рідко застосовуються на практиці. Незважаючи на це, слід відзначити привабливість аукціону як відкритого торгу 3 прозорими цінами, за якою економічна рента квоти належить уряду. 3 іншого боку, зрозуміло, що виробники можуть «лобіювати» уряд 3 метою залишити економічну ренту у себе.

Система управління поставками в АПК Канади передбачає i розміщення нових квот у випадку зростання споживання на національному рівні. Механізм розміщення нових квот заснований на їх пропорційному розподілі, при цьому не виключається спеціальне розміщення нових квот за домовленостями 3 провінціями. Квота поділяється на дві категорії первинну та вторинну. Перша-це постійна або базова величина, а друга є тимчасовою. Так, коли попит на продукцію зростає, але невідомо, що буде на ринку далі, збільшується вторинна квота. Якщо зростання попиту можна вважати постійним, тоді вторинна квота перетворюється у постійну (первинну). Цей підхід виправдовує себе в умовах збільшення ринку, зокрема, за його несталого зростання у короткому періоді, оскільки дозволяє пов'язати різні тимчасові явища зростання ринку зі збільшенням випуску квот, однак фермери поділяють і ризик, що це збільшення споживання може бути не тривалим.

У межах Канадської системи управління 
поставками в АПК ключовими елементами, що забезпечують економічну ефективність механізму застосовування квот $\epsilon$, по-перше, наявність ефективних ферм з мінімальними витратами, та, подруге, прозорий, легкий та простий у використанні метод передання квот від одного володаря до іншого, що дозволяє здійснення цієї операції з мінімальними зусиллями. Отже, ринок квот, як складник системи управління поставками, повинен, по-перше, сигналізувати тримачам квот про їх цінність, що дозволить розміщувати квоти серед тих форм, які можуть їх використати найкращим чином, i, по-друге, мінімізувати бюрократичні методи з їх розміщення та пряме втручання в цей ринок. Існує декілька шляхів передання квоти, які розрізняються принципово за підходом: продавати - купувати квоти чи брати ïx у тимчасове володіння (оренду). Перший підхід характеризується постійним характером володіння та використання квоти, другий - тимчасовим (зазвичай, рік або менше). Ці два підходи мають свої переваги та в ідеальній системі вони повинні співіснувати разом. Канадська система управління поставками в АПК розвивалася протягом майже 50 років у напрямку дозволу передання квот на постійний основі, саме так як продаж майна між фермерами. Оренда квоти в основному була заборонена 3 незрозумілих причин, але нині відбуваються зміни, за якими деякі провінції вже дозволили оренду квоти через угоди 3 активів, що практично імітує рентні операції.

Система квотування в АПК Канади передбачає квотні ринкові механізми, що полягають у проведенні формальних аукціонів 3 фермерських квот, які організують агенції зі збуту. Під час цих аукціонів фермери розміщують свої пропозиції 3 купівлі та продажу квот, агенція зі збуту порівнює їх та встановлює ринкову ціну. Всі пропозиції нижче цієї ціни задовольняються, та квоти передаються від одних тримачів до інших. Зазвичай агенція зі збуту проводить один аукціон на місяць, що означає, що наступні операції з передачі квот відбудуться тільки через місяць. Результати аукціону публікуються. Не через аукціон можуть проходити тільки два види операцій: по-перше, це продаж квот родичам; подруге, надання усього пакету акцій іншому фермеру. При цьому у деяких провінціях замість аукціону агенція зі збуту дозволяє передання квот через приватних брокерів або рекламу в газетах та інших 3МІ. Але є обов'язкова вимога отримати дозвіл агенції зі збуту на будь-яке передання квот. Крім цього деякі агенції зі збуту донині практикують передання квот тільки разом з переданням частини майна фермера, наприклад, будинків та землі. Виконання операцій 3 передання квот пов'язане 3 певними видатками, що впливає на вартість цих операцій. Відповідно майже всі агенції видають дозвіл на передання квот в обмін на певний збір, це загальноприйнята практика. Ці збори можна інтерпретувати як податок. У деяких провінціях для певних продуктів існують заборони передання квот з одної території до іншої у межах навіть однієї провінції, при цьому більшість агенцій зі збуту не дозволяють передавати квоти фермам за межами провінцій. Останнім часом певна частина квот, що розміщені в провінції, отримала статус федеральних, відповідно вони можуть продаватися між провінціями, але це дуже невеликий відсоток.

Вхід і вихід із системи квотування в АПК Канади порівняно нескладні та доступні (зокрема, вхід) для кожного фермера (учасника) з умовою, що він спроможний купити квоти. Механізм обміну квот також сприяє тому, що фермери з високими видатками залишають галузь. При цьому вони завжди можуть побачити вартість квот на ринку. Відсоток фермерів, що залишають галузь 3 системою управління поставами, є вищим в порівнянні з галузями без цієї системи. Отже, прозорий та відкритий обмін квотами сприяє відтоку з галузі фермерів з високими видатками та відчиняє двері для нових фермерів, які вірять, що зможуть втримати видатки на низькому рівні. Це сприяє структурній перебудові всередині галузі. Ефективність системи квот також залежить від свободи руху квот між регіонами. Якщо така свобода існує, то квоти будуть передані до регіонів 3 нижчими видатками та більшими доходами, забезпечуючи збільшення загального економічного доходу за рахунок порівняльної переваги. Критика на адресу системи управління поставками пов'язана, зокрема, з високою ціною квоти. Добре відомо, що висока економічна рента генерує високі ціни на місцеві продукти, які акумулюються у дисконтованій вартості квот. Це положення підтверджується на практиці, так, ціна квоти в молочній галузі у низці провінцій Канади знаходиться в межах 20 тис. кан. доларів на одну корову, в результаті, щоб утримувати стадо з 100 корів необхідно купити квот на 2 млн. кан. доларів. Висока ціна квоти має два ефекти. Перший - це обмеження притоку нових фермерів через труднощі знаходження фінансування цих інвестицій. Незважаючи на це, наявні дані свідчать, що в Канаді існує достатньо багато фермерів, що можуть знайти такі засоби. Другий, більш важливий, ефект пов'язаний з тим, що якщо фермер вже заінвестував у квоти, то будь-які зміни політики розвитку галузі буде складніше виконати, оскільки він намагатиметься втримати існуючу систему квот. Чим менше обмежень матиме система квот, тим більше нових фермерів зможуть купувати та продавати квоти; взяття квоти в тимчасову оренду (квотний рент) повинно бути дозволене; ця процедура повинна бути простою, а переміщення квот між регіонами повинно здійснюватися вільно. Якщо подібна система буде розроблена та впроваджена, то це принесе додатковий дохід фермерам та економіці в цілому.

Висновки i перспективи подальших розвиток. Які ж висновки для аграрного сектору України можна зробити з вищевиконаного аналізу Канадської системи управління поставками? Поперше, система управління поставками забезпечує соціальну стабільність для фермерів та споживачів. При цьому виробники отримують додатковий дохід від зростання цінності квоти та постійний дохід в результаті регульованих цін на агропродукцію. Це допомагає вирішити основну проблему села підвищення соціальної стабільності та залучення 
молоді у сільськогосподарське виробництво. Подруге, система управління поставками підвищує внутрішньогалузеву ефективність шляхом фінансування i проведення наукових досліджень в інтересах усіх виробників агропромислового комплексу. По-третє, система управління поставками включає в себе переміщення квот, що дозволяє фермерам 3 відносно низькими видатками купувати більше квот, ніж фермерам з високими видатками, у т.ч. в інших регіонах. Тим самим посилюється конкуренція всередині галузі, що забезпечує збільшення іiі ефективності в цілому. По-четверте, система ефективно захищає місцевих фермерів від імпорту. Канадська система управління поставками має значний вплив на уряд, що дозволяє блокувати різні політичні рішення, скеровані проти фермерів. Система об'єднує фермерів та сприяє кращому захисту їхніх інтересів.

Таким чином, канадський досвід створення та функціонування системи управління поставками в агропромисловому комплексі, за нашою думкою, може бути цікавим та корисним в умовах ринкового реформування сільського господарства України, зокрема, як досвід застосування агрологістики у такий високорозвиненій та високоефективній постіндустріальній країні, як Канада, що, як i Україна, відзначається важливою роллю аграрного сектора в економіці держави та подібною його спеціалізацією.

\section{References:}

1. Agrarna logìstika (materìali blìc-opituvannâ ekspertìv) [Agrologistics (expert quiz results)]. Logìstika. Problemi ta rǐsennâ: mižnarodnij naukovo-praktičnij žurnal [Logistics. Problems and solutions: international scientific and practical journal], 2013, Vol. 4, pp. 16-25. (In Ukrainian).

2. Barikello R. Sterelûhin A. V. Kanadskaâ sistema upravleniâ postavkami v sel'skom hozâjstve, otličitel'nye osobennosti i vozmožnosti primeneniâ [Canadian system of supply management in agriculture: main features and possibilities of application]. Materialy III Vserossijskogo kongressa èkonomistov-agrarnikov [Proceedings of the II allRussian Congress of agricultural economists]. Part I. Moscow, 2006, pp. 208-213. (In Russian).

3. Kosareva T. V. Agrarna logìstika: sutnìst' ta bagatoaspektnìst' [Agricultural logistics: essence and multidimensionality]. Ekonomika APK [The economy of agribusiness], 2008, Vol. 10, pp. 37-43. (In Ukrainian).

4. Kučerova Â. Komentarì na temu «Agrarna logìstika» [Comments on agrologistics]. Logistika. Problemi ta rišennâ: mižnarodnij naukovo-praktičnij žurnal [Logistics. Problems and solutions: international scientific and practical journal], 2013, Vol. 4, pp. 46-50. (In Ukrainian).

5. Olìnik Â. B., Smirnov İ.G. Mižnarodna logistika: navčal'nij posibnik [International logistics: learning guide]. Kyiv, 2011, 544 p.

6. Smirnov I. G. Agrologistika po-gollandski [Agrologistics: Dutch experience]. Logistics, 2008, Vol. 9, pp. 1315. (In Russian).

7. Smirnov Ì. G., Šmatok O. V. Agrologìstika v Ukraïnì: sučasnij stan, problemi ta perspektivi rozvitku [Agrologistics in Ukraine: modern state, problems, and prospects of development]. Logìstika. Problemi ta rišennâ: mižnarodnij naukovo-praktičnij žurnal [Logistics. Problems and solutions: international scientific and practical journal], 2013, Vol. 4, pp. 26-37. (In Ukrainian).

8. Sumec' O. M. Aktual'nìst' zaprovadžennâ logìstiki v gospodars'ku diâl'nìst' pìdpriêmstv APK [The relevance of the introduction of logistics in the economic activity of agricultural enterprises]. Logistika. Problemi ta rišennâ: mižnarodnij naukovo-praktičnij žurnal [Logistics. Problems and solutions: international scientific and practical journal], 2013, Vol. 4, pp. 38-45. (In Ukrainian).

9. Sumec' O. V. Problemi pìdviŝennâ efektivnostì logìstičnoï dîâl'nostì APK Ukraïni [Issues of increasing the efficiency of logistics activities in Ukrainian agribusiness]. Logistika. Problemi ta rišennâ: mižnarodnij naukovopraktičnij žurnal [Logistics. Problems and solutions: international scientific and practical journal], 2013, Vol. 6, pp. 35-39. (In Ukrainian).

10. Čuhraj H. I. Agrarna logìstika ta vertikal'na ìntegraciâ bìznesu [Agrologistics and vertical business integration]. Logistika. Problemi ta rǐšennâ: mižnarodnij naukovo-praktičnij žurnal [Logistics. Problems and solutions: international scientific and practical journal], 2013, Vol. 4, pp. 51-56. (In Ukrainian). 